\title{
Rusland: Fra afmagt til stormagt
}

\section{Karsten J. Møller}

\section{Rusland er en vanskelig aktør i det internationale system, og landets selvopfattelse gør ikke samar- bejdet med andre nationer nemmere}

Der var ikke mange i Rusland, der begræd det kommunistiske systems opløsning. Det havde stået klart siden sidste halvdel af 1980'erne, at der var tale om et fallitbo. Der var mangel på stort set alle forbrugsprodukter, om det så var noget så banalt som håndsæbe. Der var derfor i befolkningen store forventninger til markedsøkonomiens herligheder. Disse alt for store forventninger blev ikke indfriet i Jeltsins periode som præsident. Der opstod derfor en ganske udbredt sovjet-nostalgi i løbet af 1990'erne. For nok var det kommunistiske system håbløst, men det sørgede i det mindste for en vis social sikkerhed, hvis man vel at mærke holdt sig inden for systemets rammer. Da Vladimir Putin var blevet udnævnt til fungerende præsident den 31. december 1999, udtalte han kort tid efter på et spørgsmål fra en tv-journalist om netop denne udbredte nostalgi, at den, der ikke begræder Sovjetunionens opløsning, har intet hjerte, men den, der forsøger at skrue udviklingen tilbage, har ingen hjerne.

Med opløsningen af det sovjetiske imperium var det anderledes. Rigtig mange begræd imperiets sammenbrud. Og det gør de stadig. Derfor ramte Putin en udbredt folkestemning, da han for et par år siden udtalte, at Sovjetunionens sammenbrud var den største geopolitiske katastrofe i det 20. århundrede. Det russiske imperium havde været en af verdens stormagter siden det 17 . århundrede, og dets afløser, Sovjetunionen, var den ene af de to supermagter under Den Kolde Krig. USSR's opløsning betød, at Rusland fra en supermagtsstatus sank ned til i bedste fald at være en regional stormagt, om ikke af andre grunde, så fordi man stadig besad verdens 
næststørste atomslagstyrke. Fra midten af 1990'erne kunne man knap nok tale om en russisk stormagt.

Omfanget af sammenbruddet kan vel bedst illustreres ved nogle få tal. Sovjetunionen omfattede i midten af 1980'erne et areal på ca. 22,4 millioner kvadratkilometer (en halv gang så stort som USA). I 1992 var Sovjetimperiets arvtager, Rusland, skrumpet ind til et areal på ca. 17 millioner kvadratkilometer og var nu på størrelse med Rusland i det 17. århundrede. Det indebar, at nøgleområder, der var vigtige for bl.a. industri- og landbrugsproduktion, fx Ukraine, Belarus og de tre baltiske lande, men også de centralasiatiske lande med deres energiforekomster, var blevet selvstændige nationer. Sovjetunionens befolkningstal var midt i 1980'erne på ca. 266 millioner. Ruslands befolkning androg i 1992 ca. 147 millioner, og den er som bekendt siden faldet til ca. 142 millioner.

Det sovjetiske BNP var i 1985 verdens tredjestørste. I midten af 1990'erne var Ruslands BNP faldet til langt under halvdelen af det sovjetiske. Den russiske økonomi var på størrelse med Hollands, hvilket er et spinkelt grundlag, hvis man vil agere stormagt. Først i 1999 fik Rusland en beskeden vækst i BNP; fra 2000 accelererede den med en gennemsnitlig vækststigning på 6-7 procent om året, ikke mindst på grund af stigende energi- og råvarepriser. Inden den økonomiske krise for alvor ram- te i efteråret 2008, var den russiske økonomi verdens 8. største.

"Et Rusland, der ikke er en stormagt, har ingen eksistensberettigelse", pointerede min gode ven, generaloberst Leonid Grigorijevitsj Ivashov, når vi drøftede disse spørgsmål. Han var dengang chef for forsvarsministeriets internationale afdeling, og jeg var forsvarsattaché i Rusland. I dag er han vicedirektør for Akademiet for geopolitisk videnskab i Moskva. Om det er hans egen formulering, skal jeg ikke kunne sige, men den er ganske dækkende for tænkningen i patriotiske kredse. $\mathrm{Og}$ der er ikke mange russere, der ikke er patrioter. Så Putins bemærkning, der vakte bestyrtelse i den vestlige verden, var velanbragt $i$ en indenrigspolitisk sammenhæng. Hans pointe er tillige, at det sovjetiske imperiums sammenbrud førte til, at USA kom til at fremstå som unipol i det internationale system, hvilket Rusland efter bedste evne har forsøgt at modvirke siden midten af 1990'erne.

Sammenbruddet af det sovjetiske imperium førte til en fornyet diskussion i den russiske politiske elite om russisk identitet, samtidig med man var i færd med at finde frem til et nyt politisk og økonomisk system, en ny geopolitisk orientering, nye udenlandske politiske og økonomiske partnere. Rusland geografiske position mellem Europa, Asien og den muslimske verden og med meget få naturlige grænser har formet landets geopolitiske, udenrigspolitiske 
og indenrigspolitiske udvikling. Rusland har aldrig rigtigt været en integreret del af Europa, hverken politisk eller økonomisk, men heller ikke af Asien på trods af at den russiske ekspansion først og fremmest fandt sted mod øst omfattende mere end 80 procent af det russiske territorium. Men når det kommer til stykket, har Rusland altid set mest mod vest og har været langt mere kulturelt integreret med Vesten, end både russere og vesterlændinge normalt vil erkende; men det er selvfølgelig en personlige fortolkning af russisk kulturhistorie.

\section{Fire udenrigspolitiske retninger}

I Gorbatjovs og Sjevardnadzes sidste år i spidsen for USSR formuleredes konceptet om 'Den ny politiske tænkning”, der anerkendte, at verden er karakteriseret af gensidig afhængighed og gensidige forbindelser, det vi i dag kalder globalisering, hvilket mindsker betydningen af nationale interesser og militære trusler.

Man gennemførte en forsigtig tilnærmelsespolitik til Vesten, hvilket resulterede $\mathrm{i}$ adskillige våbenkontrolaftaler og i accepten af tysk genforening og opløsning af Warszawapagten. Dermed bidrog den sovjetiske politik i betydelig grad til Den Kolde Krigs ophør. Man kan lidt kynisk sige, at man gjorde en dyd af en nødvendighed, for man var ikke i stand til at skabe det økonomiske fundament, der kræves af en supermagt.

Boris Jeltsin støttede i sine første år som præsident en provestlig udenrigspolitik, hvilket var en logisk konsekvens af hans bestræbelser på at indføre demokrati og markeds$\varnothing$ konomi. Hans nærmeste medarbejdere var en gruppe af liberale demokrater som Gaidar, Kosyrev, Tjubais og til dels Tjernomyrdin. De ønskede alle en hurtig russisk økonomisk og politisk integration med den vestlige verden. Man så EU, IMF og Verdensbanken som afgørende økonomiske partnere, mens man med indgåelsen af START-II aftalen i 1993 håbede på et nyt og nært strategisk partnerskab med USA. Denne retning var dominerende i russisk udenrigspolitik i perioden 1992-93, den såkaldte euforiske periode.

Personkredsen, der stod for denne politik, blev i den russiske befolknings øjne stærkt kompromitteret for deres ansvar for gennemførelsen af den økonomiske chokpolitik, men også for deres udenrigspolitiske linje, som Dr. Nadja Arbatova formulerer det i sin sønderlemmende kritik: "På de fleste områder fulgte Rusland i hælene på Vesten og fremkaldte dermed den udbredte opfattelse af en endeløs række af indrømmelser, som bragte selve ideen om samarbejde med Vesten i miskredit og førte til en langt mere selvhævdende russisk politik". (Russian Foreign Policy After the Dissolution of the USSR). 
Man så bort fra de potentielle forskelle mellem Rusland og Vesten vedrørende væsentlige regionale og globale problemer. En række af disse forskelle havde udgangspunkt i divergerende sikkerhedsinteresser, der ikke mindst skyldes det forhold, at Rusland både er en europæisk og asiatisk magt.

Den anden retning betegnede sig selv som internationalister. De ønskede - og ønsker fortsat - at genoprette imperiet, hvis opløsning de ikke kan forlige sig med. De er overbeviste om, at befolkningerne i den tidligere Sovjetunion i virkeligheden ønsker imperiets genrejsning. Det er kun de lokale politiske eliter, der har interesse i opsplitningen. De ønsker imidlertid ikke en genforening gennemført med militær magt, men ser politisk og økonomisk pression som en mere farbar vej. De kræver, at Vesten anerkender, at Rusland har et særligt ansvar og dermed også særlige rettigheder i det såkaldt 'nære udland'.

Deres holding til Vesten er præget af skepsis, og de tenderer til at være 'isolationister'. De foretrækker et politisk og økonomisk samarbejde med alternative partnere, som $\mathrm{fx}$ Kina og Indien og sågar Iran. De er stærke fortalere for russisk våbeneksport og nuklear teknologi, kort sagt alt hvad der tjener russiske økonomiske interesser. Oprindeligt var det kommunisterne og de meget nationalistiske kredse, der stod for denne retning, men man kan gen- kende mange træk i de sidste års russiske udenrigspolitik fra denne skole, der vel må siges at have fundet gehør i dele af den politiske elite i Kreml, først og fremmest i gruppen af de såkaldte 'siloviki', d.v.s. de magthavere, der kommer fra sikkerhedsstrukturerne.

Den tredje retning kaldes den demokratisk pragmatiske. Denne retning understregede nødvendigheden af at definere Ruslands sikkerheds- og udenrigspolitiske prioriteter på grundlag af den geopolitiske situations realiteter og de interne politiske og $ø$ konomiske problemer. De gik ind for et snævert økonomisk samarbejde med Vesten, men lagde vægt på, at man skulle varetage russiske interesser og ikke gå på kompromis af hensyn til økonomisk samarbejde og bistand.

Denne retnings fortalere var bl.a Javlinskij, Arbatov og Lukin. Der var i denne retning to forskellige syn på 'det nære udland'. Den ene gruppe $\varnothing n s k e d e$ at gøre Rusland attraktiv for disse lande gennem indrømmelser og fleksibilitet, mens den anden gruppe ønskede en mere håndfast linje, især over for Ukraine, der er og bliver det mest følsomme og betændte problem i russisk indenrigsog udenrigspolitik. I sin første præsidentperiode frem til 2003 tilhørte Vladimir Putin vel nærmest denne retning, indtil den amerikanske politik under George W. Bush fik ham skubbet delvis over i den internationalistiske retning. 
Den sidste retning var den såkaldt reaktionære-pragmatiske retning, med Sjirinovksij som hovedfigur. Den ønskede imperiet genoprettet, om nødvendigt med magt. Det ideologiske grundlag er storrussisk nationalisme, den kristne ortodokse kirke og antisemitisme. Retningen er udpræget anti-vestlig. Den er ligesom den først beskrevne retning blevet marginaliseret, dog ikke i samme grad. Mange af dens ideer lever i bedste velgående i højrenationalistiske kredse.

Den anden og den tredje retning smeltede sammen og der opnåedes ganske bred enighed om russisk udenrigspolitik i perioden 1994-96.

\section{Fndret geostrategisk position}

Det stod klart, at russisk integration med Vesten var en illusion. Man lagde derfor vægt på at styrke integrationen i SNG, både den politiske og økonomiske, men også den militære dimension. Etablering af kollektiv sikkerhed fik høj prioritet. Rusland arbejdede hårdt for SNG's anerkendelse som regional organisation med observatørstatus i FN. Rusland involverede sig i fredsbevarende aktioner i bl.a. Tadsjikistan og Georgien, hvilket udviklede sig til et af de mest kontroversielle emner i russisk sikkerhedspolitik. De øvrige medlemmer af SNG ønskede ikke at gå nær så langt i det politiske, økonomiske og militære samarbejde, hvorfor SNG har udviklet sig til en tom skal.
I den russiske politiske elite erkendte man i denne periode, at den strategiske situation var ved at ændre sig i Ruslands disfavør. NATO planlage en udvidelse med tre tidligere medlemmer af Warszawa-pagten og agtede ikke at tage hensyn til russiske indvendinger. Man havde tilsyneladende mistet interessen for Rusland i skuffelse over den indenrigspolitiske udvikling. Forsøget på at udvikle SNG viste sig at være en veritabel fiasko, og den første tjetjenske krig 1994-96 satte spørgsmålstegn ved Den Russiske Føderations sammenhængskraft og bidrog til den opfattelse, at Rusland befandt sig i en eksistentielt meget sårbar position.

Den militære elite fremhævede, at styrkeforholdet mellem Rusland og NATO havde ændret sig dramatisk i Ruslands disfavør. Rusland havde trukket sig $1500 \mathrm{~km}$ tilbage fra Schwerin, Magdeburg og Prag til Kursk og Smolensk. Fra et geostrategisk synspunkt var Moskvas Militærdistrikt, der i mere end 300 år havde været 'bagland', blevet 'et frontdistrikt'.

Beslutningen om NATO-udvidelsen understregede for Rusland, at Vesten aldrig ville acceptere, at et nyt europæisk sikkerhedssystem byggede på OSCE, hvilket var Ruslands præference. I stedet tegnede ser sig et mere og mere klart billede af et NATO-centreret system, hvorfra Rusland ville være udelukket. Bitterheden i den russiske politiske elite 
var stor og gav næring til de stærke anti-vestlige tendenser, der stadig er fremherskende i Rusland.

Samtidig gjorde Rusland en anden og nok så vigtig erkendelse. 'The New World Order' som George H. W. Bush talte om i 1989 indebar, at USA ikke længere behøvede at føre en inddæmningspolitik over for Rusland. USA prioriterede at bevare stabiliteten i det post-sovjetiske rum Nok så vigtigt var det, at USA heller ikke forsøgte at fylde det geostrategiske magttomrum ud i Østeuropa, Kaukasus og Centralasien. Men i midten af 1990'erne begyndte USA at udfordre den russiske dominans i Østeuropa, Centralasien og Sydkaukasus. Clinton-administrationens udenrigspolitiske koncept varslede en udbredelse af demokrati og markedsøkonomi under USA's ledelse, 'The Liberal Order'. I Europa var udvidelsen af NATO et af midlerne til at udbrede den amerikanske indflydelse. I russisk optik er de mange smukke ord om demokrati og menneskerettigheder en gang tynd fernis over gammeldags magtpolitik, hvilket man fik bekræftet, da George W. Bush i 2002 udgav en ny national sikkerhedsstrategi, hvor anvendelse af væbnet magt til udbredelse af demokrati var en option. Dokumentet lagde heller ikke skjul på, at USA ikke ville tillade opkomsten af en ligeværdig strategisk konkurrent.

Hele denne udvikling udfordrede den traditionelle russiske dominans i det post-sovjetiske rum.

\section{Primakovs fire principper}

I 1996 blev Jevgenij Primakov udenrigsminister. Han formulerede en pragmatisk, men i bund og grund antivestlig politik. For det første skulle Rusland aktivt forsvare sine interesser, men undgå direkte konfrontation. For det andet skulle Rusland stræbe efter et internationalt system baseret på multipolaritet. For det tredje skulle Rusland udvikle sine forbindelser med de vigtigste stater i verden i overensstemmelse med Ruslands potentiale og status som kernevåbenmagt. Disse relationer skulle bygge på princippet om ligeværdighed.

Sidst men ikke mindst skulle russisk udenrigspolitik bygge på en så bred national konsensus som muligt. Primakov, der både nationalt og internationalt var højt respekteret, fik bragt russisk udenrigspolitik på en kurs, der netop havde bred politisk og folkelig opbakning

Så meget desto større blev skuffelsen, vreden og frustrationerne, da Ruslands afmagt blev udstillet på den mest ydmygende måde, da NATO i marts 1999 indledte luftbombardementet af Serbien i forbindelse med Kosovo-krisen. Det var den russiske opfattelse, at landets interesser var blevet fuldstændigt tilsidesat, og Ruslands position som stormagt var blevet undermineret, fordi beslutningen om at anvende væbnet magt var blevet taget $i$ NATO-rådet og ikke i FN's Sikker- 
hedsråd, hvor Rusland i givet fald ville have kunnet nedlægge veto.

Den russiske reaktion udstillede landets svaghed og afmagt. Samarbejdet med NATO blev suspenderet, dog ikke med SFOR i Bosnien, det bilaterale samarbejde mellem Rusland og de enkelte NATO-lande blev midlertidigt afbrudt, og to diplomater fra NATO-repræsentationen i Moskva blev vist ud. Samarbejdet i Permanent Joint Council, hvor Rusland søgte at opnå et privilegeret strategisk partnerskab, ophørte og blev først genoptaget i 2002 i forbindelse med oprettelsen af NATO-Rusland Rådet i 2002.

Kosovo-krisen blev et vendepunkt, hvis effekt ikke må undervurderes. Den anti-vestlige holdning blev yderligere forstærket og har i brede kredse udviklet sig til noget, der ligner had først og fremmest til USA, men også til NATO.

\section{Tendenser i Putins udenrigspolitik}

\section{I begyndelsen af 2000 underskrev} den fungerende præsident, Vladimir Putin, en ny national sikkerhedskoncept, hvor illusionen om Rusland som stormagt med globale interesser og forpligtelser (hvilket Primakov mente, Rusland havde) tilsyneladende var opgivet. Ruslands interne svagheder erkendes og analyseres hudløst ærligt, og man drager den logiske konsekvens heraf: Rusland er en vigtig regional stormagt med et enormt potentiale.
Ikke mindst er Rusland en kernevåbenmagt, hvilket indebærer en særlig status i det internationale system. Vesten beskrives ikke som en strategisk partner, men kan tid efter anden være en nyttig samarbejdspartner, men interessekonflikterne vil fortsat være til stede.

Primakovs fire principper er stadig en væsentlig del af grundlaget for Putins udenrigspolitik, men den antivestlige holdning er nedtonet. Rusland skal, understreger han, føre en multivektor politik, d.v.s. at man ikke binder sig til sig entydigt til bestemte samarbejdspartnere. Udenrigspolitikken skal først og fremmest være pragmatisk og tjene russiske økonomiske interesser. Ruslands økonomiske udvikling er nemlig forudsætningen for Ruslands genrejsning som stormagt. Og netop genrejsningen af Rusland som stormagt var i virkeligheden det mål, han satte sig, da han overtog præsidentposten.

Det fremgår af hans såkaldte manifest, Rusland ved årtusindskiftet, der blev offentliggjort den 31. december 1999, samme dag som Jeltsin overdrog præsidentposten til ham. Men Rusland skulle også være en del af globaliseringen, og i praksis betød det en økonomisk integration med Vesten.

Han arbejdede derfor energisk for russisk medlemskab af WTO, men optagelsesforhandlingerne trak i langdrag til stor skuffelse for Putin, og meget tyder nu på, at den russi- 
ske interesse er stærkt aftagende. Rusland blev i 1997 formelt medlem af G8, og Putin tillagde deltagelsen stor betydning, ikke mindst fordi det blev betragtet som en formel anerkendelse af, at Rusland hører til blandt verdens mægtigste nationer. Ved G8 mødet i Skt. Petersborg 2006 erklærede Putin, at Rusland er en energisupermagt, der bør være ledende i bestræbelserne på at sikre den globale energisikkerhed. Det blev som bekendt nærmest ignoreret.

EU er Ruslands vigtigste handelspartner, og det var derfor naturligt at søge et tættere samarbejde med EU. Ved EU's udvidelse med de tidligere Warszawapagt-lande blev russiske interesser tilgodeset i betydeligt omfang Men forholdet til EU har udviklet sig til et langvarigt tovtrækkeri om en ny partnerskabsaftale og aftale om et nyt energicharter. Forholdet mellem EU og Rusland er i stigende grad blevet et sikkerhedsspørgsmål, ikke mindst på grund af stridigheder mellem Rusland på den ene side og først og fremmest de baltiske lande og Polen på den anden side. Rusland foretrækker i stigende grad at samarbejde på bilateral basis med en udvalgt kreds af EU-medlemmer, hvilket ikke bidrager til et mere snævert samarbejde med EU.

I forholdet til USA oplevede Putin en lang række skuffelser hvad angår våbenkontrolområdet, missilforsvar, NATO-udvidelserne og USA's be- stræbelser på at få strategisk fodfæste i Centralasien og Kaukasusområdet. Men først og fremmest havde Putin forventet, at USA var rede til at indgå i et strategisk partnerskab, ikke mindst efter Putins bidrag til den amerikanske kamp mod terrorismen efter 11. september 2001. Det var imidlertid ikke tilfældet. USA's beslutning om at invadere Irak uden et FN-mandat, tændte advarselslamperne i Kreml.

Roserevolutionen i Georgien og Orangerevolutionen i Ukraine bekræftede den russiske politiske elites værste anelser. USA og den vestlige verden forsøgte at gennemføre et regimeskifte ved subversiv virksomhed i Rusland og Belarus, en Birkerevolution, som den blev døbt.

I samme periode oplevede Rusland enestående økonomiske fremgang på grund af de stigende energi- og råvarepriser. Det medvirkede til at udvide det russiske udenrigspolitiske råderum. Russisk udenrigspolitik blev mere og mere markant.

Putins politik i hans anden præsidentperiode var præget af tre primære mål: At genvinde den tabte indflydelse på det eurasiske kontinent; at imødegå og begrænse USA's 'containment' og splittelsespolitik i forhold til Rusland; at udbygge det økonomiske samarbejde med andre lande, som kan bidrage til russisk økonomisk vækst, fx Kina, Indien, Brasilien og Iran. Man søger tillige nye partnere i Latinamerika og Afrika. 


\section{Münchentalen}

Med Putins berømte tale i München i februar 2007 blev der sendt et tydeligt signal til den vestlige verden: For det første: accepter Rusland som det er, d.v.s. stop indblandingen i interne russiske forhold. For det andet: Vesten skal behandle Rusland som en ligeværdig partner og for det tredje: efterlevelsen af disse to punkter er forudsætningen for et samarbejde med Rusland, der skal tage udgangspunkt i parternes gensidige interesser.

Konflikten med Georgien viste, at Rusland er parat til aktivt at forsvare sine vitale interesser i sit nærområde. Det skete på et tidspunkt, hvor den russiske politiske elite var overbevist om, at Rusland havde genvundet sin stormagtsposition gennem sin stærke økonomiske position samt status som energisupermagt. Imidlertid var det russiske prestigetab ved aktionen i Georgien og den efterfølgende diplomatiske anerkendelse af Sydossetien og Abkhasien, ikke mindst blandt SNG-landene, men også Kina, formentlig en overraskelse. Det har i hvert fald vanskeliggjort russisk politik over for disse lande.

Hvorvidt den økonomiske krise, der har ramt Rusland hårdt, vil bidrage til at nedjustere ambitionsniveauet, vil tiden vise. Den nationale sikkerhedskoncept som præsident Medvedev underskrev i efteråret 2008 , er ligesom den forrige kon- cept hudløs ærlig med hensyn til Ruslands interne problemer: Den ensidige afhængighed af energi- og råvareeksport, de store sociale og sundhedsmæssige problemer, der er medvirkende til den katastrofale demografiske udvikling o.s.v.

Men koncepten ser stadig Rusland som en global stormagt, der relativt er blevet styrket på grund af den vestlige verdens politiske og økonomiske svækkelse.

USA har fået ny politisk ledelse, der ønsker at genetablere et tillidsforhold til Rusland, hvilket er forudsætningen for et samarbejde om de væsentlige politiske temaer. Indtil videre er Rusland tøvende og behersket positiv. Man vil se sikre tegn på en reel kursændring. Man nærer frygt for, at den amerikanske politik i virkeligheden er den, som vicepræsident Biden gav udtryk for i et interview i Wall Street Journal, inden han begav sig på rejse til Georgien og Ukraine for at forsikre dem om, at USA støttede deres bestræbelser på at blive medlemmer af NATO.

I interviewet gav han udtryk for, at Ruslands økonomiske og politiske fundament var relativt svagt, og USA derfor ikke behøvede at tage særlige hensyn til russiske interesser. Det er derfor næppe nogen overraskelse, at man er skeptisk i Kreml.

Hermed er vi fremme ved denne artikels pointe. Rusland er en vanskelig aktør i det internationale system. Den russiske selvopfattelse som stormagt gør ikke nødvendigvis 
samarbejdet med andre nationer nemmere. Henry Kissinger har udtrykt det på sin egen veltalende måde (Diplomacy 1994): "The Paradox of Russian History lies in the continuing ambivalence between messianic drive and pervasive sense of insecurity. In its ultimate aberration, this ambivalence generated a fear, that unless the empire expanded, it would implode."

Man taler i den vestlige presse om en ny kold krig, fordi Rusland nu forsøger og i et vist omfang er i stand til at varetage det, som landet anser for at være sine nationale interesser. Den vestlige verden har i årene efter Den Kolde Krigs ophør i betydeligt omfang ignoreret legitime russiske interesser og bevidst og systematisk holdt landet ude fra reel indflydelse i de økonomiske og politiske strukturer, der overlevede Den Kolde Krig. Der bredte sig hurtigt en stemning i Vesten: Vi vandt Den Kolde Krig, og det er os, der bestemmer. Ruslands svaghed og afmagt i 1990'erne og begyndelsen af dette årti gjorde en sådan politik mulig. Den vestlige verden overvejede ikke på noget tidspunkt seriøst at inddrage Rusland i et gensidigt forpligtende samarbejde. Det var besværligt, russerne er besværlige, og deres indvendinger og forslag blev mødt med en holdning, der bedst kan beskrives som: Vi hører, hvad I siger, men vi gør som det passer os. På grund af Ruslands svagheder var det muligt. Men var det klogt? Man fremkaldte et 'Versailles-syndrom'. Hvordan kan det være, at (Vest-) Tyskland efter Anden Verdenskrig blev behandlet så generøst, når Rusland, som trods alt bidrog positivt og substantielt til afslutningen af Den Kolde Krig, bliver behandlet på en så ydmygende og arrogant måde? I russisk optik er det ren magtpolitik, der har til formål at inddæmme landet og begrænse dets indflydelse.

Rusland er i et vist omfang tilbage som stormagt og er begyndt at give Vesten et modspil. Derfor er det positivt, at den amerikanske præsident og NATOs generalsekretær har givet så tydeligt udtryk for, at vi må prøve at genetablere et tillidsforhold og et fornyet samarbejde med Rusland. Det bliver ikke nemt. Der kan ikke ses bort fra, at interesserne ikke altid er sammenfaldende. Det lykkes forhåbentligt, men det kræver, at begge parter, og ikke mindst medierne, afvikler de 'koldkrigstankebaner', der aktiveres som en rygmarvsrefleks, så snart de politiske problemer spidser til.

Karsten Jakob Møller er pensioneret generalmajor, $i$ dag senioranalytiker koordinator for indsatsområdet Forsvars- og sikkerhedspolitik ved DIIS, Dansk Institut for Internationale Studier. 